\title{
Faktor-Faktor yang Berpengaruh pada Niat Memanfaatkan Insentif Pajak pada Masa Pandemi COVID-19
}

\author{
Naniek Noviari ${ }^{1}$ \\ Fakultas Ekonomi dan Bisnis \\ Universitas Udayana, Indonesia
}

\author{
I Gst Ayu Eka Damayanthi² \\ Fakultas Ekonomi dan Bisnis \\ Universitas Udayana, Indonesia
}

\begin{abstract}
Surel : novikeinan@unud.ac.id
ABSTRAK

Penelitian ini bertujuan untuk memverifikasi faktor-faktor yang berpengaruh pada niat pemanfaatan insentif pajak pada masa pandemi COVID-19. Populasi penelitian adalah seluruh wajib Pajak (WP) UMKM yang terdaftar di Bali dengan menggunakan metode accidental sampling. Data dikumpulkan dari 100 responden melalui kuesioner dengan menggunakan google forms. Alat analisis yang digunakan dalam penelitian ini adalah analisis regresi linear berganda. Hasil penelitian menunjukkan variabel persepsi pengetahuan pajak, risiko pajak, internal influence, external influence, self efficacy, dan controlability berpengaruh positif pada niat pemanfaatan fasilitas pajak. Hasil penelitian ini dapat digunakan sebagai bahan evaluasi dalam menyusun dan mengimplementasikan kebijakan fiskal terutama tentang fasilitas pajak dalam penanganan pandemi COVID-19.
\end{abstract}

Kata Kunci: Persepsi Pengetahuan Pajak; Risiko Pajak; Internal Influence; External Influence; Self Efficacy; Controlability; Niat Pemanfaatan Fasilitas Pajak.

\section{Factors Influencing Intentions to Use Tax Incentives During the COVID-19 Pandemic}

\section{ABSTRACT}

This study aims to verify the factors that influence the intention to use tax incentives during the COVID-19 pandemic. The research population is all MSME taxpayers registered in Bali using the accidental sampling method. Data was collected from 100 respondents through a questionnaire using google forms. The analytical tool used in this research is multiple linear regression analysis. The results showed that the perceived tax knowledge, tax risk, internal influence, external influence, self-efficacy, and controlability variables had a positive effect on the intention to use tax facilities. The results of this study can be used as evaluation material in preparing and implementing fiscal policies, especially regarding tax facilities in handling the COVID-19 pandemic.

Keywords: $\quad$ Perception Of Tax Knowledge; Tax Risk; Internal Influence; External Influences; Self-Efficacy; Controlability; Intention To Use Tax Facilities.

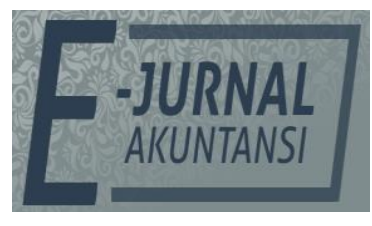

e-ISSN 2302-8556

Vol. 31 No. 11

Denpasar, November 2021

Hal. 2936-2948

DOI:

10.24843/EJA.2021.v31.i11.p20

PENGUTIPAN:

Noviari, N., \& Damayanthi, I.G.A.E. (2021). Faktor-Faktor yang Berpengaruh pada Niat Memanfaatkan Insentif Pajak pada Masa Pandemi COVID19. E-Jurnal Akuntansi, 31(11), 2936-2948

RIWAYAT ARTIKEL: Artikel Masuk: 31 Oktober 2021 Artikel Diterima: 28 November 2021

Artikel dapat diakses : https://ojs.unud.ac.id/index.php/Akuntansi/index 


\section{PENDAHULUAN}

Dampak pandemi Corona Virus Disease 2019 (COVID-19) dirasakan hampir di semua sektor. Jumlah UMKM di Bali pada akhir 2019 mencapai 327.310 UMKM, dengan persentase pertumbuhan 4 persen di tahun 2019. Meruntut data dari Dinas Koperasi dan UKM Provinsi Bali, per 16 April 2020, jumlah UMKM yang terdampak Covid-19 sudah mencapai 18.583 UMKM. Jumlah ini akan terus bertambah mengikuti perkembangan di kabupaten/kota masing-masing.

UMKM banyak yang tidak beroperasional selama pandemi COVID-19. Di sisi lain, kewajiban perpajakan tetap harus dipenuhi padahal UMKM tidak memiliki dana untuk membayar pajak. Pengusaha akan memerlukan insentif pajak dalam hal ini. Pemerintah Indonesia memberikan insentif pajak bagi setiap wajib pajak (WP). Menteri Keuangan menerbitkan peraturan Nomor 44/PMK.03/2020 tentang Insentif Pajak Untuk WP Terdampak Pandemi COVID19 (PMK 44/2020). PMK 44/2020 diharapkan dapat meringankan beban WP. Insentif ini hanya berlaku sampai dengan Desember 2020. Tapi berdasarkan data hanya sedikit WP memanfaatkan fasilitas tersebut. Pemerintah mencatat realisasi pemberian insentif pajak untuk pelaku usaha hingga 31 Agustus 2020 baru mencapai Rp18,85 triliun atau 15,6 persen dari alokasi anggaran sebesar Rp120,61 triliun (DDTCNews, 2020).

PMK 44/2020 diharapkan dapat meringankan beban WP. Tapi disisi lain ada banyak persyaratan formal dan administrasi yang harus dipenuhi oleh WP untuk memanfaatkan fasilitas ini. WP harus mendaftar secara online, melaporkan laporan realisasi setiap bulan, dan tetap membuat e_billing. Ini akan menjadi dilema bagi WP. Syarat administrasi ini memerlukan waktu, sumber daya internet, dan sumber daya manusia (SDM) untuk mengerjakannya sedangkan di masa pandemi sumber daya WP terbatas dan banyak pegawai WP yang diberhentikan. Lebih jauh lagi, WP tetap harus membayar 30 persen dari angsuran Pajak Penghasilan Pasal 25, padahal kondisi keuangan WP sangat terbatas. Disamping itu, waktu pemanfaatan fasilitas ini hanya sampai Desember 2020. Berdasarkan penjelasan diatas, penting untuk dilakukan riset, faktor-faktor apa saja yang berpengaruh pada niat WP untuk insentif pajak.

Theory of planned behavior (TPB) dapat digunakan sebagai landasan teori untuk memverifikasi faktor-faktor yang berpengaruh pada niat untuk memanfaatkan Fasilitas Pajak. Kemudahan penggunaan yang dirasakan dan kegunaan yang dirasakan (pengetahuan akan manfaat) dan persepsi risiko mempengaruhi niat untuk menggunakan sesuatu (Ajzen, 1985), (Sheikhshoaei \& Oloumi, 2011), dan (Suryaningrum et al., 2009). Norma subyektif mempengaruhi niat untuk menggunakan sesuatu (Ajzen, 1991), (Bhattacherjee, 2000), (Hsu \& Chiu, 2004), dan (Sheikhshoaei \& Oloumi, 2011). Norma subyektif mempengaruhi niat berperilaku dalam menggunakan teknologi (Hsu \& Chiu, 2004). Norma subyektif mencakup dua bentuk pengaruh yaitu pengaruh internal dan pengaruh external (Bhattacherjee, 2000). Pengaruh sosial yang penting berakar dari keluarga, pasangan hidup, kerabat, atasan, rekan dalam bekerja dan acuan lainnya yang berkaitan dengan suatu perilaku (Ajzen, 2006). Keberadaan faktor pendukung memberikan peran penting dalam hal pengendalian atas kontrol perilaku (Ajzen, 2005). Individu akan merasa lebih puas dengan perilaku jika mereka berpikir bahwa mereka mampu melakukannya (Bandura, 1977). Persepsi kemudahan yang 
akan diperoleh berdasarkan pengetahuan/keterampilan yang dimiliki dalam melakukan suatu perilaku (self efficacy) dan kemampuan individu mengendalikan faktor pendukung terutama kepemilikan akan SDM yang kompeten dan waktu (persepsi controllability) berperan dalam niat perilaku individu (Ajzen, 2002).

Sikap terhadap perilaku merupakan persepsi individu akan manfaat atau kerugian yang mungkin diperoleh jika melakukan atau tidak melakukan suatu perilaku (Ramdhani, 2011). Ketika individu memiliki pengetahuan akan manfaat suatu perilaku, maka ia memiliki kehendak untuk melakukan perbuatan tertentu. Pengetahuan pajak berpengaruh positif pada niat penggunaan fasilitas pelaporan pajak melalui $e$-filing (Krisdayana \& Fitria, 2020) dan (Syakura, 2017). Pengetahuan pajak yang dimiliki WP memungkinkan WP untuk mengetahui dan mengerti bagaimana tata cara pembayaran pajak, penyetoran maupun pelaporan pajak, memberikan kepastian mereka untuk menggunakan fasilitas e-filing dalam melaporkan pajak (Krisdayana \& Fitria, 2020). Semakin banyak pengetahuan mengenai pajak yang WP dapatkan maka akan semakin meningkatkan niat WP untuk menggunakan e-filing (Syakura, 2017). Hal yang sama juga didukung oleh hasil penelitian lainnya terkait fasilitas pajak Tax Amnesty. Semakin banyak pengetahuan perpajakan yang dimiliki WP maka akan semakin tinggi tingkat kemauan WP untuk mengikuti Program Tax Amnesty (Da'le' et al., 2017), (Hadisy et al., 2017), (Pakata, 2018), dan (Trisnasari et al., 2017). Seseorang yang memiliki pengetahuan perpajakan yang tinggi, akan sadar akan hak dan kewajibannya tanpa harus dipaksakan ataupun diancam dengan sanksi dan hukuman. Dengan memiliki pengetahuan yang tinggi, WP akan mengerti tarif serta tata cara mengikuti Tax Amnesty sehingga niat mengikuti Tax Amnesty akan tinggi (Trisnasari et al., 2017). Berdasarkan pemaparan sebelumnya, maka dikembangkan hipotesis sebagai berikut.

$\mathrm{H}_{1}$ : Pengetahuan perpajakan berpengaruh positif pada niat pelaku WP UMKM di

Bali untuk memanfaatkan fasilitas pajak (PMK 44 Tahun 2020).

Persepsi risiko adalah persepsi atas ketidakpastian, konsekuensi, dan kewajiban yang dihadapi ketika melakukan aktivitas tertentu (Hsu \& Chiu, 2004). Persepsi risiko berpengaruh pada penggunaan e-filing untuk pelaporan SPT Tahunan WPOP (Febryanti et al., 2020). Risiko WP bingung dalam menggunakan e-filing, risiko double record identitas diri yang akan menyulitkan WP dalam mengurus kewajiban pelaporannya, risiko server Direktorat Jenderal Pajak tidak berfungsi karena banyaknya yang mengakses e-filing secara bersamaan, akan mempengaruhi WP dalam penggunaan $e$-filing dalam pelaporan SPT (Febryanti $e t$ al., 2020). Persepsi risiko (perceived risk) merupakan salah satu faktor yang menjadikan WP enggan menggunakan e-filing (Sabilla \& Baridwan, 2018). Persepsi risiko berpengaruh negatif pada penggunaan sistem e-filing (Noch \& Pattiasina, 2017) dan (Schaupp et al., 2010). Semakin rendah persepsi risiko WP orang pribadi dalam mengoperasikan e-filing maka Wajib Pajak akan sering menggunakan sistem e-filing (Noch \& Pattiasina, 2017). Persepsi risiko berpengaruh negatif pada minat penggunaan mobile banking (Alalwan et al., 2016). Persepsi risiko berpengaruh negatif terhadap minat penggunaan bertransaksi dengan $e$-commerce (Pavlou, 2003). Hasil yang berbeda ditemukan peneliti lainnya. Persepsi risiko tidak berpengaruh terhadap penggunaan e-filing bagi WP Orang Pribadi (Saripah 
et al., 2016). Berdasarkan pemaparan sebelumnya, maka dikembangkan hipotesis sebagai berikut.

$\mathrm{H}_{2}$ : Persepsi risiko pajak berpengaruh negatif pada niat pelaku WP UMKM di Bali untuk memanfaatkan fasilitas pajak (PMK 44 Tahun 2020).

Norma subyektif mempengaruhi niat untuk menggunakan sesuatu (Ajzen, 1991), (Bhattacherjee, 2000), (Hsu \& Chiu, 2004) dan (Sheikhshoaei \& Oloumi, 2011). Norma subyektif mempengaruhi niat berperilaku dalam menggunakan teknologi (Hsu \& Chiu, 2004). Norma subyektif mencakup dua bentuk pengaruh yaitu pengaruh internal dan pengaruh external (Bhattacherjee, 2000). Pengaruh sosial yang penting berakar dari keluarga, pasangan hidup, kerabat, atasan, rekan dalam bekerja dan acuan lainnya yang berkaitan dengan suatu perilaku (Ajzen, 2006). Norma subyektif merupakan faktor yang paling kuat dalam mempengaruhi niat perilaku untuk menggunakan aplikasi (Wibowo \& Tambotoh, 2015). Norma subyektif berpengaruh positif pada niat penggunaan online tax filing (Anuar \& Radiah, 2010), (Fu et al., 2006), (C. Lu et al., 2010), dan (Tallaha et al., 2014). Jika WP memiliki lingkungan yang menggunakan e-filing, maka hal tersebut dapat mendorongnya untuk menggunakan e-filing (Nanda, 2018). Lingkungan sosial berpengaruh pada adopsi e-filing pada negara berkembang (Chaouali et al., 2016). WP lebih cenderung memiliki niat tinggi untuk mengadopsi layanan e-filing ketika dia percaya bahwa keluarga, teman, dan koleganya berpikir bahwa dia harus menggunakan sistem tersebut (Chaouali et al., 2016). Hal yang sama juga didukung oleh hasil penelitian lainnya terkait fasilitas pajak Tax Amnesty. Norma subyektif berpengaruh positif pada niat WP mengikuti program Tax Amnesty (Andriawan et al., 2017). Hasil yang berbeda ditemukan peneliti lainnya. Norma subyektif tidak berpengaruh pada niat penggunaan $e$-filing (Jimantoro \& Tjondro, 2014).

$\mathrm{H}_{3}$ : Internal influence berpengaruh positif pada niat pelaku WP UMKM di Bali untuk memanfaatkan fasilitas pajak (PMK 44 Tahun 2020).

Dalam konteks penelitian ini, pelaku WP UMKM di Bali akan berniat untuk memanfaatkan fasilitas pajak (PMK 44 Tahun 2020) apabila adanya tuntutan/keinginan dari lingkungan internal (keluarga) agar memanfaatkan fasilitas ini (persepsi individu akan seberapa kuat keinginan keluarga untuk memanfaatkan fasilitas ini), adanya sugesti dari lingkungan external (tetangga, rekan bisnis, konsultan pajak, dan pegawai pajak) bahwa mereka memiliki keyakinan positif bahwa pemanfaatan fasilitas pajak (PMK 44 Tahun 2020) merupakan kegiatan yang menguntungkan bagi mereka, sebaliknya niatnya akan rendah bila mereka mempersepsikan pemanfaatan fasilitas pajak akan mengakibatkan lebih banyak kegiatan administratif daripada nilai/manfaat pajak yang diperoleh. Hipotesis yang disusun berdasarkan penjelasan, adalah sebagai berikut.

$\mathrm{H}_{4}$ : External influence berpengaruh positif pada niat pelaku WP UMKM di Bali untuk memanfaatkan fasilitas pajak (PMK 44 Tahun 2020).

Kontrol perilaku persepsian adalah persepsi seseorang tentang tingkat kompleksitas pelaksanaan suatu perbuatan (Hogg \& Vaughan, 2005). Kontrol perilaku dapat juga diartikan sebagai pemahaman seseorang mengenai tingkat kompleksitas dalam melakukan perbuatan berdasarkan pengalaman terdahulu dan kendala yang dapat dicari solusinya dalam melakukan suatu perbuatan 
(Feldman, 1995). Seseorang yang mempunyai sikap dan norma subyektif yang mendukung dalam melakukan perbuatan tertentu akan sangat bergantung pada dukungan kontrol perilaku persepsian yang ia miliki. Keberadaan faktor pendukung memberikan peran penting dalam hal pengendalian atas kontrol perilaku. Begitu pula sebaliknya, semakin sedikit faktor pendukung yang dirasakan oleh suatu individu maka individu tersebut akan kesulitan untuk memahami perilaku yang dilakukan (Ajzen, 2005). Seorang yang memiliki sikap yang positif, dukungan dari orang-orang disekitar dan sedikitnya hambatan untuk melakukan suatu perilaku, maka orang itu akan memiliki niat yang kuat dibandingkan ketika memiliki sikap yang positif dan dukungan dari orang sekitar namun banyak hambatan yang ada untuk melakukan perilaku tersebut. Dalam konteks penelitian ini, pelaku WP UMKM di Bali akan berniat untuk memanfaatkan fasilitas pajak (PMK 44 Tahun 2020) apabila pelaku berkeyakinan bahwa pelaku memiliki pengetahuan (self-efficacy), kontrol (controllability) pada sumber daya manusia dan waktu untuk memanfaatkan insentif pajak tersebut.

Self-efficacy mencerminkan kepercayaan diri individu dalam kemampuan pengetahuan yang dimilikinya untuk menggunakan e-filing (Lee, 2009). Selfefficacy berhubungan positif dengan niat perilaku (Luarn \& Lin, 2005). Jadi, ketika seorang WP memiliki tingkat kepercayaan yang tinggi dalam pengetahuan keterampilannya tentang $e$-filing, dia cenderung mengembangkan harapan yang tinggi untuk mengadopsinya (Chaouali et al., 2016). Hipotesis yang disusun berdasarkan penjelasan adalah sebagai berikut.

$\mathrm{H}_{5}$ : Self Efficacy berpengaruh positif pada niat pelaku WP UMKM di Bali untuk memanfaatkan Fasilitas Pajak (PMK 44 Tahun 2020).

Kurangnya beberapa sumber daya yang dimiliki seseorang merupakan hambatan untuk melakukan perilaku tertentu (Taylor \& Todd, 1995). Ketersediaan sumber daya manusia yang kompeten dan ketersediaan waktu berpengaruh pada niat menggunakan layanan e-government (J. Lu et al., 2008). Jika seorang individu percaya bahwa dia memiliki faktor sumber daya yang memadai, lebih cenderung untuk membentuk ekspektasi perilaku yang tinggi terhadap adopsi e-filing (Chaouali et al., 2016). Hipotesis yang disusun berdasarkan penjelasan di atas adalah sebagai berikut.

$\mathrm{H}_{6}$ : Persepsi controllability berpengaruh positif pada niat pelaku WP UMKM di Bali untuk memanfaatkan fasilitas pajak (PMK 44 Tahun 2020).

\section{METODE PENELITIAN}

Penelitian ini dilakukan pada WP pelaku UMKM di Bali. Lokasi tersebut dipilih karena meruntut data dari Dinas Koperasi dan UKM Provinsi Bali, per 16 April 2020, jumlah UMKM yang terdampak Covid-19 sudah mencapai 18.583 UMKM. Populasi dalam penelitian ini adalah pelaku UMKM di Bali. Berdasarkan data Dinas Koperasi dan UMKM, pelaku UMKM pada akhir 2019 di Bali mencapai jumlah 327.310. Teknik penentuan sampel yang digunakan dalam penelitian ini adalah teknik accidental sampling yang dengan rumus Slovin diperoleh 100 sampel. Penelitian ini menggunakan 3 (tiga) kriteria responden. Pertama, responden merupakan pemilik UMKM. Kedua, responden memiliki akumulasi peredaran bruto dibawah Rp 4,8 Milyar dalam 1 tahun. Ketiga, responden memiliki NPWP yang terdaftar di Bali. Metode pengumpulan data yang digunakan dalam 
penelitian ini adalah dengan menggunakan kuesioner. Kuesioner berupa daftar pertanyaan/pernyataan tertulis (melalui fitur google forms ) disebar secara online kepada pemilik UMKM di Bali.

Teknik analisis data yang digunakan dalam menguji hipotesis penelitian ini adalah regresi linear berganda. Sebelum uji regresi dilakukan terlebih dahulu model yang akan diuji harus memenuhi syarat uji asumsi klasik. Analisis regresi linier berganda menghasilkan informasi yang berkaitan dengan uji kelayakan model (uji F), uji hipotesis (uji t) dan koefisien determinasi. Analisis linier berganda dilakukan untuk mengetahui pengaruh variabel-variabel bebas terhadap variabel terikat. Adapun model regresi berganda dalam penelitian ini adalah sebagai berikut.

$Y=\alpha+\beta 1 X_{1}+\beta_{2} X_{2}+\beta_{3} X_{3}+\beta 4 X_{4}+\beta 5 X_{5}+\beta 6 X_{6}+\varepsilon$

Keterangan:

Y : Niat Pemanfaatan Fasilitas Pajak

$\mathrm{X}_{1} \quad$ : Persepsi Pengetahuan Pajak

$\mathrm{X}_{2} \quad$ : Persepsi Risiko Pajak

$\mathrm{X}_{3} \quad$ : Persepsi Internal Influence

$\mathrm{X}_{4} \quad$ : Persepsi External Influence

$\mathrm{X}_{5} \quad$ : Persepsi Self Efficacy

$\mathrm{X}_{6} \quad$ : Persepsi Controllability

a $\quad$ : konstanta

$\beta_{1}-\beta_{3}$ : koefisien regresi

$\varepsilon \quad$ : error

\section{HASIL DAN PEMBAHASAN}

Responden dalam penelitian ini adalah pelaku UMKM di Bali. Data dikumpulkan dengan menyebarkan kuesioner secara daring ke anggota Himpunan Pengusaha Muda Indonesia wilayah Bali. Ringkasan pengiriman dan pengembalian kuesioner dapat dilihat pada Tabel 1.

Tabel 1. Ringkasan Pengiriman dan Pengembalian Kuesioner

\begin{tabular}{lc}
\hline Kuesioner & Jumlah \\
\hline Kuesioner Tersebar & 200 \\
Kuesioner Kembali & 125 \\
Tidak memiliki NPWP & $(25)$ \\
Kuesioner yang Digunakan & 100 \\
\hline
\end{tabular}

Sumber: Data Penelitian, 2021

Pada Tabel 1, ditunjukkan bahwa kuesioner yang tersebar ke responden adalah 200. Setelah konfirmasi yang dilakukan maka didapatkan kuesioner yang kembali sebanyak 125 kuesioner. Dari 125 kuesioner terisi, 25 kuesioner tidak bisa dipakai karena responden tidak memiliki NPWP di Bali sehingga hanya 100 kuesioner yang digunakan dalam penelitian. Jumlah kuesioner yang digunakan dalam penelitian sebesar 80 persen dari kuesioner yang kembali tapi 100 persen dari syarat responden sesuai dengan rumus Slovin.

Distribusi frekuensi jawaban responden atas indikator variabel penelitian yang terdiri atas niat pemanfaatan fasilitas pajak $(\mathrm{Y})$, persepsi pengetahuan pajak $\left(X_{1}\right)$, risiko pajak $\left(X_{2}\right)$, internal influence $\left(X_{3}\right)$, external influence $\left(X_{4}\right)$, self efficacy $\left(X_{5}\right)$, dan controllability $\left(\mathrm{X}_{6}\right)$ dijelaskan detail pada paragraph berikut. 
Jawaban responden atas pernyataan yang diajukan menunjukkan jawaban terkonsentrasi pada jawaban setuju dan sangat setuju. Ini berarti sebagian besar responden cenderung dan memutuskan untuk memanfaatkan fasilitas insentif pajak untuk WP terdampak Covid-19. Jawaban responden atas pernyataan yang diajukan menunjukkan bahwa untuk semua pertanyaan, sebagian besar responden menjawab setuju (74 persen keatas), diikuti jawaban Sangat Setuju (13 persen keatas). Hanya sebagian kecil responden menjawab Tidak Setuju (6 persen kebawah) dan Sangat Tidak Setuju (1 persen). Ini menunjukkan bahwa sebagian besar responden berpersepsi positif akan pengetahuan pajak yang dimilikinya terkait insentif pajak PMK 44 Tahun 2020.

Jawaban responden atas pernyataan yang diajukan menunjukkan bahwa untuk semua pertanyaan, sebagian besar responden menjawab setuju (61 persen keatas), diikuti jawaban Sangat Setuju (13 persen keatas). Hanya sebagian kecil responden menjawab Tidak Setuju (26 persen kebawah) dan Sangat Tidak Setuju (1 persen). Sebagian besar responden berpersepsi bahwa kegiatan yang tidak dapat diprediksi dan sulit dimengerti adalah kegiatan yang buruk (72 persen keatas). Sebagian besar responden berpersepsi bahwa kegiatan pemanfaatan insentif pajak merupakan kegiatan yang tidak dapat diprediksi dan sulit dimengerti (61 persen keatas). Dengan kata lain, sebagian besar responden berpersepsi bahwa kegiatan pemanfaatan insentif pajak merupakan kegiatan yang buruk. Tapi disisi lain, sebagian besar responden memahami dan setuju akan konsekuensi/kewajiban formal yang harus dipenuhi jika memanfaatkan fasilitas insentif pajak ini (76 persen keatas).

Jawaban responden atas pernyataan yang diajukan menunjukkan bahwa untuk semua pertanyaan, sebagian besar responden menjawab setuju (73 persen keatas). Sebagian besar responden berpersepsi bahwa responden biasanya akan mengikuti apa yang dianjurkan orangtua dan saudaranya (73 persen keatas). Lebih jauh lagi, orang tua dan saudara responden mendukung responden untuk memanfaatkan insentif pajak (80 persen keatas).

Jawaban responden atas pernyataan yang diajukan menunjukkan bahwa untuk semua pertanyaan, sebagian besar responden menjawab setuju (61 persen keatas). Sebagian besar responden berpersepsi bahwa responden biasanya akan mengikuti apa yang dianjurkan teman, tetangga, petugas pajak, konsultan pajak dan rekan bisnisnya (61 persen keatas). Lebih jauh lagi, teman, tetangga, petugas pajak, konsultan pajak dan rekan bisnis responden mendukung responden untuk memanfaatkan insentif pajak (80 persen keatas).

Jawaban responden atas pernyataan yang diajukan menunjukkan bahwa untuk semua pertanyaan, sebagian besar responden menjawab setuju (75 persen). Sebagian besar responden berpersepsi bahwa kurangnya pengetahuan bukan menjadi penghambat yang besar untuk memanfaatkan Insentif Pajak (75 persen keatas).

Jawaban responden atas pernyataan yang diajukan menunjukkan bahwa untuk semua pertanyaan, sebagian besar responden menjawab setuju (74 persen keatas). Sebagian besar responden berpersepsi bahwa kurangnya SDM dan waktu bukan menjadi penghambat yang besar untuk memanfaatkan insentif pajak (74 persen keatas). 
Analisis regresi yang digunakan adalah analisis regresi berganda. Pada Tabel 2, ditunjukkan bahwa berdasarkan hasil uji, nilai koefisien determinasi yang diperoleh adalah sebesar 0,901. Nilai determinasinya menjadi 0,901 $\times 100$ persen $=$ 90,1 persen. Hal ini mengindikasikan bahwa Niat Pemanfaatan Fasilitas Pajak (Y) dijelaskan sebesar 90,1 persen oleh variabel pengetahuan perpajakan (X1), persepsi risiko $\left(X_{2}\right)$, internal influence $\left(X_{3}\right)$, external influence $\left(X_{4}\right)$, self efficacy $\left(X_{5}\right)$ dan Controllability $\left(\mathrm{X}_{6}\right)$, sisanya dijelaskan oleh variabel lain yang tidak dimasukkan ke dalam model atau penelitian. Pada tabel 2 ditampilkan hasil uji F.

Pada tabel 3 dapat dilihat bahwa berdasarkan hasil uji nilai $\mathrm{F}$ hitung sebesar 150.993. Nilai F hitung ini lebih besar dari nilai $F$ tabel sebesar 2,20 dan nilai signifikansi $\mathrm{F}$ sebesar 0,000 nilai ini lebih kecil dari 0,05 , sehingga dapat disimpulkan bahwa terdapat pengaruh signifikan pengetahuan perpajakan $(X 1)$, persepsi risiko $\left(X_{2}\right)$, internal influence $\left(X_{3}\right)$, external influence $\left(X_{4}\right)$, selfefficacy $(X 5)$ dan controllability $\left(\mathrm{X}_{6}\right)$ terhadap variabel terikat yaitu niat pemanfaatan fasilitas pajak (Y) secara simultan.

Hasil pengujian hipotesis dirangkum pada Tabel 2. Semua hipotesis telah diuji dalam penelitian ini, 5 (lima) hipotesis berhasil diterima dan 1 (satu) hipotesis ditolak.

\section{Tabel 2. Hasil Uji Hipotesis}

\begin{tabular}{|c|c|c|c|c|c|}
\hline Model & $\begin{array}{l}\text { Unstandardi } \\
\text { Coefficients } \\
\text { B }\end{array}$ & \begin{tabular}{l|} 
ized \\
Std. \\
Error
\end{tabular} & $\begin{array}{l}\text { Standardized } \\
\text { Coefficients } \\
\text { Beta } \\
\end{array}$ & $\mathrm{t}$ & Sig. \\
\hline (Constant) & -.531 & .139 & & -3.833 & .000 \\
\hline $\begin{array}{l}\text { Pengetahuan Perpajakan } \\
\text { (X1) }\end{array}$ & .156 & .073 & .128 & 2.131 & .036 \\
\hline Persepsi Risiko (X2) & .213 & .068 & .186 & 3.135 & .002 \\
\hline Internal Influence (X3) & .217 & .073 & .180 & 2.958 & .004 \\
\hline External Influence (X4) & .235 & .093 & .179 & 2.522 & .013 \\
\hline Self Efficacy (X5) & .159 & .051 & .178 & 3.120 & .002 \\
\hline Controllability (X6) & .235 & .065 & .235 & 3.640 & .000 \\
\hline $\mathrm{R}$ & $: 0.952^{\mathrm{a}}$ & & & & \\
\hline R Square & $: 0.907$ & & & & \\
\hline Adjusted R Square & $: 0.901$ & & & & \\
\hline Std. Error of the Estimate & $: 0.12291$ & & & & \\
\hline F hitung & $: 150.993$ & & & & \\
\hline Sig. F & $: 0.000^{\mathrm{b}}$ & & & & \\
\hline
\end{tabular}

Berdasarkan hasil uji, Pengetahuan Perpajakan (X1) berpengaruh positif pada Niat Pemanfaatan Fasilitas Pajak (Y). Hipotesis 1 didukung. Jika nilai persepsi pengetahuan perpajakan naik maka niat pemanfaatan fasilitas pajak (Y) akan meningkat. Hasil penelitian ini konsisten dengan hasil penelitian Krisdayana \& Fitria (2020), Syakura (2017), Da'le' et al., (2017), Hadisy et al., (2017), Pakata (2018), dan Trisnasari et al., (2017). Ketika individu memiliki pengetahuan akan manfaat suatu perilaku, maka ia memiliki kehendak untuk melakukan perbuatan tertentu. Latar belakang pendidikan sebagian besar responden adalah S1 (Sarjana). Ini menunjukkan bahwa responden memiliki pengetahuan perpajakan yang 
tinggi, sehingga sadar akan hak dan kewajibannya tanpa harus dipaksakan ataupun diancam dengan sanksi dan hukuman. Pengetahuan pajak yang dimiliki WP memungkinkan WP untuk mengetahui dan mengerti bagaimana tata cara, hak, dan kewajiban pemanfaatan insentif pajak sehingga meningkatkan niat WP untuk memanfaatkan insentif pajak.

Berdasarkan hasil uji, Persepsi Risiko $\left(\mathrm{X}_{2}\right)$ berpengaruh positif pada Niat Pemanfaatan Fasilitas Pajak $(Y)$. Jika nilai persepsi risiko $\left(X_{2}\right)$ naik maka niat pemanfaatan fasilitas pajak $(\mathrm{Y})$ akan meningkat. $\mathrm{H}_{2}$ tidak didukung. Hasil ini tidak konsisten dengan temuan Sabilla \& Baridwan (2018), Noch \& Pattiasina (2017), Schaupp et al., (2010) , Alalwan et al., (2016), Pavlou (2003), dan Febryanti et al., (2020). Sebagian besar responden memang berpersepsi bahwa kegiatan pemanfaatan insentif pajak merupakan kegiatan yang tidak dapat diprediksi dan sulit dimengerti sehingga merupakan kegiatan yang buruk. Tapi disisi lain, sebagian besar responden memahami dan setuju akan konsekuensi/kewajiban formal yang harus dipenuhi jika memanfaatkan fasilitas insentif pajak ini (76 persen keatas). Sehingga walaupun kewajiban formal/konsekuensi pemanfaatan insentif pajak meningkat, niat pemanfaatan insentif pajak tetap meningkat.

Berdasarkan hasil uji, internal influence $\left(X_{3}\right)$ berpengaruh positif pada Niat Pemanfaatan Fasilitas Pajak (Y). Variabel External Influence $\left(\mathrm{X}_{4}\right)$ juga berpengaruh positif pada Niat Pemanfaatan Fasilitas Pajak (Y). Hipotesis 3 dan 4 didukung. Hasil riset ini tidak konsisten dengan temuan Jimantoro \& Tjondro (2014), yang menyatakan bahwa Norma subyektif tidak berpengaruh pada niat penggunaan $e$ filing.

Temuan riset ini konsisten dengan temuan Bhattacherjee (2000), Hsu \& Chiu (2004), Sheikhshoaei \& Oloumi (2011), Ajzen (2006), Wibowo \& Tambotoh ( 2015), Anuar \& Radiah (2010), Fu et al., (2006), Lu et al., (2010), Tallaha et al., (2014), Nanda, (2018), Chaouali et al., (2016), dan Andriawan et al., (2017). Norma subyektif mempengaruhi niat untuk menggunakan sesuatu. Lingkungan sosial berpengaruh pada adopsi fasilitas pajak pada negara berkembang. Jika WP memiliki lingkungan external dan internal, yang menggunakan fasilitas pajak, maka hal tersebut dapat mendorongnya untuk juga memanfaatkan fasilitas pajak. WP lebih cenderung memiliki niat tinggi untuk memanfaatkan fasilitas pajak, ketika dia percaya bahwa keluarga, teman, kolega/rekan bisnis, tetangga, pegawai pajak dan konsultan pajaknya berpikir bahwa dia harus memanfaatkan fasilitas pajak tersebut.

Berdasarkan hasil uji, Self Efficacy $\left(\mathrm{X}_{5}\right)$ berpengaruh positif pada Niat Pemanfaatan Fasilitas Pajak (Y). Hipotesis 5 didukung. Temuan riset ini konsisten dengan temuan riset dari Lee (2009), Luarn \& Lin (2005), dan Chaouali et al. (2016). Ketika seorang WP memiliki tingkat kepercayaan yang tinggi dalam keterampilannya tentang insentif pajak, dia cenderung mengembangkan harapan yang tinggi untuk memanfaatkan fasilitas insentif pajak tersebut.

Berdasarkan hasil uji, Controllability (X6) berpengaruh positif pada Niat Pemanfaatan Fasilitas Pajak (Y). Temuan riset ini konsisten dengan temuan riset dari Taylor \& Todd (1995), J. Lu et al.(2008), dan Chaouali et al. (2016). Ketersediaan sumber daya manusia yang kompeten dan ketersediaan waktu berpengaruh pada niat menggunakan fasilitas pajak. Jika seorang individu percaya bahwa dia memiliki faktor sumber daya yang memadai (SDM dan waktu) lebih cenderung 
untuk membentuk ekspektasi perilaku yang tinggi terhadap pemanfaatan fasilitas pajak tersebut.

\section{SIMPULAN}

Penelitian ini memverifikasi 6 (enam) temuan. Pertama, pengetahuan perpajakan berpengaruh positif pada niat pemanfaatan fasilitas pajak. Hal ini bermakna, semakin meningkat persepsi pengetahuan perpajakan maka semakin kuat niat pemanfaatan fasilitas pajak. Kedua, persepsi risiko berpengaruh positif pada niat pemanfaatan fasilitas pajak. Hal ini bermakna, walaupun kewajiban formal/konsekuensi pemanfaatan insentif pajak meningkat, niat pemanfaatan insentif pajak tetap meningkat. Ketiga, internal influence berpengaruh positif pada niat pemanfaatan fasilitas pajak. Semakin tinggi persepsi bahwa keluarganya berpikir bahwa dia harus memanfaatkan fasilitas pajak tersebut, maka semakin kuat niat pemanfaatan fasilitas pajak. Keempat, external influence berpengaruh positif pada niat pemanfaatan fasilitas pajak. Hal ini bermakna, semakin tinggi persepsi bahwa lingkungan external nya (teman, kolega/rekan bisnis, tetangga, pegawai pajak dan konsultan pajak) berpikir bahwa dia harus memanfaatkan fasilitas pajak tersebut, maka semakin kuat niat pemanfaatan fasilitas pajak. Kelima, self efficacy berpengaruh positif pada niat pemanfaatan fasilitas pajak. Hal ini bermakna, semakin tinggi tingkat kepercayaan akan keterampilannya tentang insentif pajak, maka semakin kuat niat untuk memanfaatkan fasilitas insentif pajak. Keenam, controllability berpengaruh positif pada niat pemanfaatan fasilitas pajak. Hal ini bermakna, semakin tinggi persepsi kepemilikan sumber daya yang memadai (SDM dan waktu), maka semakin kuat niat pemanfaatan fasilitas

Sebagian besar responden berpersepsi bahwa kegiatan pemanfaatan insentif pajak merupakan kegiatan yang tidak dapat diprediksi dan sulit dimengerti sehingga merupakan kegiatan yang buruk. Fiskus bisa mengurangi persepsi negatif WP ini melalui beberapa cara. Pertama, meningkatkan sosialisasi peraturan pajak terkait insentif. Kedua, meningkatkan pelayanan pajak (online dan offline) terkait insentif pajak.

Implikasi teoritis penelitian ini adalah penelitian ini memberikan bukti empiris Theory of Planned Behaviour dalam memprediksi faktor-faktor yang berpengaruh dalam niat pemanfaatan fasilitas pajak. Lebih jelasnya, penelitian ini memberikan bukti empiris pengaruh persepsi pengetahuan pajak, risiko pajak, internal Influence, external Influence, self efficacy, dan controllability terhadap niat pemanfaatan fasilitas pajak WP UMKM di Bali. Penelitian ini diharapkan dapat dijadikan referensi dan sumbangan konseptual bagi penelitian sejenisnya dan dapat memperluas wawasan.

Implikasi praktis penelitian ini adalah melalui penelitian ini, peneliti dapat memberikan masukan atau kontribusi positif untuk instansi atau organisasi terutama pada pengambil kebijakan fiskal dan dari hasil penelitian dapat dijadikan bahan evaluasi dalam menyusun dan mengimplementasikan kebijakan fiskal terutama tentang fasilitas pajak. Fiskus ketika mengambil kebijakan terkait fasilitas pajak harus memperhatikan variabel pengetahuan pajak, risiko pajak, internal Influence, external Influence, self efficacy, dan controllability dari Wajib Pajak sehingga niat WP untuk memanfaatkan fasilitas tersebut meningkat. 


\section{REFERENSI}

Ajzen, I. (1985). From Intentions to Actions: A Theory of Planned Behavior. In Action Control (pp. 11-39). Springer Berlin Heidelberg. https://doi.org/10.1007/978-3-642-69746-3_2

Ajzen, I. (1991). The theory of planned behavior. Organizational Behavior and Human Decision Processes, 50(2), 179-211. https://doi.org/10.1016/07495978(91)90020-T

Ajzen, I. (2002). Perceived behavioral control, self-efficacy, locus of control, and the theory of planned behavior. Journal of Applied Social Psychology, 32(4), 665683. https:// doi.org/10.1111/j.1559-1816.2002.tb00236.x

Ajzen, I. (2005). Attitudes, Personality and Behavior. Open University Press.

Ajzen, I. (2006). Constructing a TpB Questionnaire: Conceptual and Methodological Considerations.

http:// citeseerx.ist.psu.edu/viewdoc/download?doi=10.1.1.601.956\&rep $=$ rep $1 \&$ type $=$ pdf

Alalwan, A. A., Yogesh, A., Nripendra, D., \& D.Williams, M. (2016). Article information: To cite this document: About Emerald www.emeraldinsight.com. Journal of Enterprise Information Management, 29(1), 118-139.

Andriawan, I. G. D., Sujana, E., \& Yasa, I. N. P. (2017). Mengungkap Faktor-Faktor Yang Mendorong Wajib Pajak Buleleng Mengikuti Program Tax Amnesty. E-Journal S1 Ak Universitas Pendidikan Ganesha Jurusan Akuntansi Program $S 1,8(2)$.

Anuar, S., \& Radiah, O. (2010). Determinants of Online Tax Payment System in Malaysia. International Journal of Public Information Systems, 6(1), 17-32.

Bandura. (1977). Self-Efficacy: The Exercise of Control. Freeman.

Bhattacherjee, A. (2000). Acceptance of e-Commerce Services: The Case of Electronic Brokerages. Systems, Man and Cybernetics, Part A: IEE Transactions On Systems, Man, and Cybernetics, 30(4), 411-420.

Chaouali, W., Yahia, I. Ben, Charfeddine, L., \& Triki, A. (2016). Understanding citizens' adoption of e-filing in developing countries: An empirical investigation. Journal of High Technology Management Research, 27(2), 161176. https://doi.org/10.1016/j.hitech.2016.10.006

Da'le', I., Leunupun, P., \& Hiariej, N. (2017). Jurnal Ekonomi Peluang. XI(2), 234254. http://ojs.ukim.ac.id/index.php/peluang/article/view/354

Febryanti, D., Afifudin, \& Mawardi, M. C. (2020). Pengaruh Penerapan Computer Self Efficacy, Modernisasi Sistem Administrasi Perpajakan, Dan Risiko Teknologi Informasi Terhadap Penggunaan E-Filing Dalam Pelaporan Spt Tahunan WPOP (Studi Kasus Pada KPP Pasuruan ). E-Jra, 09(05), 1-17.

Feldman, R. . (1995). Understanding Psychology. Mc-Graw Hill.

Fu, J. R., Farn, C. K., \& Chao, W. P. (2006). Acceptance of electronic tax filing: A study of taxpayer intentions. Information and Management, 43(1), 109-126. https:// doi.org/10.1016/j.im.2005.04.001

Hadisy, S., Sujana, E., \& Purnamawati, A. (2017). Persepsi Wajib Pajak Mengenai Keadilan Pajak, Pengetahuan Pajak Terhadap Keberhasilan Tax Amnesty Pada Kantor Pelayanan Pajak Pratama Singaraja. E-Journal S1 Ak Universitas Pendidikan Ganesha, 8(2). 
Hogg, M. A., \& Vaughan, G. . (2005). Introduction to Social Psychology (4th Ed). Pearson Prentice Hall.

Hsu, M. H., \& Chiu, C. M. (2004). Predicting electronic service continuance with a decomposed theory of planned behaviour. Behaviour and Information Technology, 23(5), 359-373. https://doi.org/10.1080/01449290410001669969

Jimantoro, C., \& Tjondro, E. (2014). Analisis Niat Penggunaan E-Filing Di PT"X" Dan PT"Y" Surabaya Dengan Structural Equation Modeling. Tax $\mathcal{E}$ Accounting Review, 4(2), 1-8.

Krisdayana, P., \& Fitria, A. (2020). Pengaruh Pengetahuan, KeamananKerahasiaan, Kesiapan Teknologi Informasi Terhadap Efisiensi Pelaporan Pajak E-Filling. Jurnal Ilmu Dan Riset Akuntansi, 9(3), 1-19. http://jurnalmahasiswa.stiesia.ac.id/index.php/jira/article/view/2841

Lee, M. C. (2009). Factors influencing the adoption of internet banking: An integration of TAM and TPB with perceived risk and perceived benefit. Electronic Commerce Research and Applications, 8(3), 130-141. https://doi.org/10.1016/j.elerap.2008.11.006

Lu, C., Huang, S., \& Lo, P. (2010). An empirical study of on-line tax filing acceptance model: Integrating TAM and TPB. African Journal of Business Management, 4(5), 800-810.

Lu, J., Liu, C., Yu, C. S., \& Wang, K. (2008). Determinants of accepting wireless mobile data services in China. Information and Management, 45(1), 52-64. https://doi.org/10.1016/j.im.2007.11.002

Luarn, P., \& Lin, H. H. (2005). Toward an understanding of the behavioral intention to use mobile banking. Computers in Human Behavior, 21(6), 873891. https:// doi.org/10.1016/j.chb.2004.03.003

Nanda, L. (2018). Faktor-Faktor yang Berpengaruh Terhadap Penerimaan Sistem EFilling (Studi Empiris pada Wajib Pajak Orang Pribadi) [Universitas Islam Indonesia]. https://dspace.uii.ac.id/handle/123456789/11631

Noch, M. Y., \& Pattiasina, V. (2017). Persepsi Risiko Dan Kepuasan Wajib Pajak Terhadap Pengunaan Sistem E-Filling ( Survei Pada Kpp Pratama Jayapura) Pajak Terhadap Pengunaan Sistem E-Filling. November.

Pakata, R. (2018). Persepsi Wajib Pajak pada Keadilan Pajak dan Pengetahuan Pajak terhadap Keberhasilan Tax Amnesty pada Kantor Pelayanan Pajak Pratama Samarinda. EKIS (Ekonomi,Sosial Dan Bisnis), 14(2), 3436 -3530. http://e-journal.polnes.ac.id/index.php/eksis/article/view/297

Pavlou, P. A. (2003). Consumer acceptance of electronic commerce: Integrating trust and risk with the technology acceptance model. International Journal of Electronic Commerce, 7(3), 101-134. https://doi.org/10.1080/10864415.2003.11044275

Ramdhani, N. (2011). Penyusunan Alat Pengukur Berbasis Theory of Planned Behavior. Buletin Psikologi, 19(2), 55-69. https://doi.org/10.22146/bpsi.11557

Sabilla, A. N., \& Baridwan, Z. (2018). Determinan Minat Perilaku dalam Penggunaan E-Filing Sebagai Sarana Pelaporan SPT Tahunan Wajib Pajak Orang Pribadi. Jurnal Ilmiah Mahasiswa FEB Universitas Brawijaya, 6(2), 1689-1699. https://jimfeb.ub.ac.id/index.php/jimfeb/article/view/4921 
Saripah, Putri, A. A., \& Darwin, R. (2016). Pengaruh Kepercayaan , Persepsi Kebermanfaatan, Persepsi Risiko dan Kepuasan Wajib Pajak Terhadap Penggunaan E-Filing bagi Wajib Pajak Orang Pribadi di KPP Pratama Pekanbaru Tampan Tahun 2015. Akuntansi \& Ekonomika, 6, 2-16.

Schaupp, L. C., Carter, L., \& McBride, M. E. (2010). E-file adoption: A study of U.S. taxpayers' intentions. Computers in Human Behavior, 26(4), 636-644. https://doi.org/10.1016/j.chb.2009.12.017

Sheikhshoaei, F., \& Oloumi, T. (2011). Applying the technology acceptance model to Iranian engineering faculty libraries. Electronic Library, 29(3), 367-378. https://doi.org/10.1108/02640471111141106

Suryaningrum, D. ., Harymami, \& Erna, S. (2009). suryaningrum.pdf. In Universitas Teknologi Yogyakarta (Ed.), Prosiding buku 3 Seminar Nasional $V$ (pp. 25-31).

Syakura, M. A. (2017). Analisis Perilaku Wajib Pajak Terhadap Niat Menggunakan E-Filling dan Kepatuhan Wajib Pajak (Studi Pada Wajib Pajak Dengan Profesi Sebagai Dosen). Akuntabel, 14(1), 46. https://doi.org/10.29264/jakt.v14i1.1343

Tallaha, A. M., Shukor, Z. A., \& Hassan, N. S. A. (2014). Factors influencing e-filing usage among Malaysian taxpayers: Does tax knowledge matters? Jurnal Pengurusan, 40, 91-101. https:// doi.org/10.17576/pengurusan-2014-40-08

Taylor, S., \& Todd, P. A. (1995). Understanding information technology usage: A test of competing models. Information Systems Research, 6(2), 144-176. https://doi.org/10.1287/isre.6.2.144

Trisnasari, A. T., Sujana, E., \& Herawati, N. T. (2017). Pengaruh Kesadaran Wajib Pajak, Sosialisasi Perpajakan dan Pengetahuan Perpajakan Terhadap Kemauan Wajib Pajak Dalam Mengikuti Program Tax Amnesty. E-Journal S1 Ak Universitas Pendidikan Ganesha, 7(1).

Wibowo, B. S., \& Tambotoh, J. J. C. (2015). Analisis Pemanfaatan Teknologi Informasi Menggunakan Kerangka Technology Acceptance Model 3 Pada Aplikasi Data Pokok Pendidikan Dasar. Semnasteknomedia Online, 3(1), 55. https://www.mculture.go.th/mculture_th/download/king9/Glossary_about_HM_King _Bhumibol_Adulyadej's_Funeral.pdf 